JOURNAL OF CORPORATE RESPONSIBILITY

AND LEADERSHIP

InNOVATIONS IN CORPORATE SOCIAL RESPONSIBILITY

and Public Management

\title{
Social Responsibility Aspects of Companies' Insolvency
}

DOI: http://dx.doi.org/10.12775/JCRL.2018.020

YuRY KaRALEU

Department of Business Administration, The School of Business of Belarusian State University, Minsk, Belarus

e-mail: yykorolev@sbmt.by

\begin{abstract}
The issue: Over the last 20 years corporate social responsibility (CSR) has become one of the standard business practices. Despite the positivity and optimism that CSR brings to the corporate table, its relationship with the companies' insolvency are poorly investigated, leading to concern about its impact.

Purpose: The author intends to assess the state of the art of disclosing social responsibility aspects of companies' insolvency as a case of CSR and seeks the answer for the question if the definite pension and wage benefits in case of corporate insolvencies should be included into management reports.

Methodology: Literature sources and public domain data analysis, analysis of local and international legislative documents and other regulatory official papers, investigation of the practice of corporate social responsibility all around the world, consolidated financial statements of companies, etc. have been used to formulate conclusions. Comparative studies of Belarusian legislation and the relevant international wage and pension protection mechanisms and instruments were analysed for making more informed and well-argued conclusions and recommendations based upon these studies.
\end{abstract}

Findings: Evidence shows that together with the employment issues, occupational health and safety aspects, training and education matters, etc. companies are expected to disclose such information as employees' and pensioners' claims in case of company insolvency through disclosing relevant non-financial information in management reports. 
Value: The research may be the basis for the further practical implementation of disclosure requirements on non-financial and diversity information in international guidelines and principles.

Keywords: corporate social responsibility, companies’ insolvency, wage and pension claims.

\section{Introduction}

One of the clearest definitions of corporate social responsibility, given by A. McWilliams and D. Siegel (McWilliams and Siegel, 2001, p. 117), describes CSR as actions that contribute to social good, going beyond the interests of the firm and requirements of law. Many of the environmental, political and development challenges experienced in the contemporary world as well as many recent developments in the international scene clearly demonstrate the importance of socially responsible behaviour by companies, i.e. corporate social responsibility (CSR). The need to implement the practices of CSR is driven by the lessons from experiencing such events as among others: the global financial crisis of 2007-2009 and the largest in the world's history corporate bankruptcies of Lehman Brothers Holdings Inc., Washington Mutual, Inc., WorldCom, General Motors Company, etc., the BP Deepwater Horizon oil spill, the Chernobyl and Fukushima nuclear radiation disasters, the widening gap between CEO rewards and that of others, concerns about corporate tax avoidance by multinational companies and other business behaviours faced by the society.

The concept of corporate social responsibility seems to be beneficial for everybody. From the point of view of companies, CSR provides important benefits to business in risk management, cost savings, access to capital, combating corruption, customer relationships, HR management, and their ability to innovate. Acting in a socially responsible way contributes to securing economic success and reputation in the long term. From the point of view of the world economy, CSR makes companies more sustainable and innovative, which contributes to the sustainable economic future. For the society, CSR sets values on which we can build a more consistent international community and a foundation for the transition to a sustainable economic system (EU, nd). 
From the point of view of CSR, one of the aspects of the business that impacts a wider community is social protection of job losses, wages and pension benefits in case of corporate insolvencies. The relationships between corporate insolvency and corporate social responsibility can be expressed in the following way:

Insolvency - Job Loss - Wage and Pension Benefits - Social Protection - CSR.

In case of company insolvency, employees' and pensioners' claims are social claims in the sense that they contribute to the social support and social fabric of countries in dealing with a more vulnerable segment of the population. At the same time, they are also economic claims in the sense that employees and pensioners become creditors of a liquidated bankrupt estate or in an insolvency restructuring proceeding. Accordingly, the company insolvency and satisfaction of employee claims, that range from wages, health and disability benefits to the issue of pension commitments, are of interest to legal professionals, economists and specialists in corporate social responsibility.

\section{Research aim, design, methodology and limitations}

The aim of the study is to research the interaction between social responsibility and companies' insolvency and reasons for extending CSR KPIs by indicators related to pension and wage benefits in case of insolvency. The study is focused on answering to the following research questions: (1) What are the concepts and assumptions of disclosing social and employee-related matters in corporate reports in accordance with different standards, requirements and guidelines? (2) How do companies implement those requirements in real practice? (3) What is the interaction between social responsibility and companies' insolvency? (4) Should social responsibility aspects of companies' insolvency be presented among CSR KPIs?

In order to answer these research questions, we have constructed the following structure of the study. Part 3 of this paper provides an overview of EU, ISO and GRI Guidelines approaches to CSR aspects and sustainability strategy ideas including its implementation by the leading telecommunication companies. Part 4 analyses existing schemes of protection of claims during insolvency in different jurisdictions and social responsibility aspects of companies' insolvency. Finally, in Part 5 using 
the example of Belarus, as a country with priority creditor status for employees during insolvency, the reasons for changing CSR KPIs of non-financial social and employee matters are disclosed.

Literature sources and public domain data analysis, analysis of existing legislation and instruments for the implementation of the EU Directive, ILO conventions, OECD Guidelines, ISO standards, Sustainability Reporting Guidelines by Global Reporting Initiative and comparative studies have been used to formulate conclusions.

For understanding existing differences between jurisdictions and approaches for the treatment of wage and pension claims, terminology specifics and the challenge of comparative research should be taken into consideration. The biggest problem is that different kinds of terminology can have the same sense and meaning. For example, unsecured claims can be called and have the same meaning as non-preferred claims, ordinary claims or current claims. Some jurisdictions refer to priority claims; others call them preferred claims, preferences or preferential claims. Different funding mechanisms for wage and pension protection very often referred to as a guarantee fund, a government agency, a guarantee association, etc. and usually are called 'funds'. Such funds together with different insolvency insurance schemes also are mentioned as a guarantee institution or a guarantee scheme. Different jurisdictions use the words insolvency and bankruptcy to distinguish different stages in an insolvency proceeding or to distinguish commercial or consumer treatment of financial distress, whereas other jurisdictions use the terms interchangeably. Reference to insolvent debtors can refer to corporations, unincorporated companies, business trusts, partnerships or other business enterprises in some countries, whereas in other jurisdictions, the insolvency laws do not cover businesses such as partnerships, trusts or individuals. Therefore, it is important to bear in mind that certain descriptions or terminologies must be understood in the context in which they are being referred to, in terms of the broader social, economic and legal framework of a jurisdiction.

In addition, it should be taken into account that some sources used for conducting this research have been published fairly long ago. For example, for the purposes of calculation of the global statistics, the study by Janis Sarra (Sarra, 2008, p. 9) refers to the status of law as it stood in force on May 1, 2008. Such sources do not reflect the latest tendencies in the treatment of wage and pension claims and therefore 
do not take into consideration legal amendments related to this issue in different jurisdictions, but they help to understand the global approach and tendency.

\section{Disclosure of non-financial social and employee matters}

\subsection{Conceptual approach}

In order to answer to the first question stated above ('What are the concepts and assumptions of disclosing social and employee-related matters in corporate reports in accordance with different standards, requirements and guidelines?') we have investigated sustainability strategy, which in line with CSR ideas are used in terms of increasing efficiency, optimising business and expanding production.

A framework of 17 goals (Sustainable Development Goals, SDG) was adopted by the members of the United Nations, aimed at reducing poverty, protecting the planet, and ensuring prosperity for all. Together with actively embodied ecological and societal responsibility, they are regarded as a long-term value driver for economic benefits. However, there are not present any linkages between SDG and eliminating or reducing the consequences of company insolvency (Barbier and Burgess, 2017, p. 2).

In the EU, the European Commission promotes CSR and encourages enterprises to adhere to international guidelines and principles. To promote these ideas, Directive 2014/95/EU of the European Parliament and of the Council on disclosure of non-financial and diversity information by certain large undertakings and groups (Directive) entered into force on 6 December 2014 (European Union, 2014). Companies concerned are required to disclose in their management reports relevant information on policies, outcomes and risks, including due diligence that they implement, and relevant non-financial key performance indicators concerning environmental aspects, social and employee-related matters, respect for human rights, anti-corruption and bribery issues, and diversity on the boards of directors (European Commission MEMO/14/301, 2014). This information should be useful for understanding companies' development, performance, position and the impact of their activity, rather than a comprehensive and detailed report is to be prepared. Companies concerned started applying the Directive as of 2018, disclosing 
information relating to the 2017 financial year (European Union, 2014).

As stated by the Directive, from the point of view of social and employee matters, which are the object of our study, companies are expected to disclose information concerning the implementation of fundamental conventions of the International Labour Organization, diversity issues, employment issues, etc. A company may consider disclosing KPIs based on social and employee matters aspects such as (European Union, 2014):

- age, gender or educational and professional backgrounds and other aspects of diversity;

- employees entitled to parental leave, by gender;

- workers who participate in activities with a high risk of specific accidents or diseases;

- the number of occupational accidents, types of injury or occupational diseases;

- employee turnover;

- the ratio of employees working under temporary contracts, by gender;

- average hours of training per year per employee, by gender;

- employee consultation processes;

- the number of employed persons with disabilities.

Companies may find it useful to rely on broadly recognised, high-quality frameworks, for instance, the OECD Guidelines for multinational enterprises (OECD, 2011), the ILO Tripartite Declaration of Principles concerning Multinational Enterprises and Social Policy (ILO, 2017), or ISO 26,000 (ISO, 2014). For example, ISO 26,000 by the International Organisation for Standardization (ISO), a specialized international agency for standardisation composed of the national standards bodies of more than 160 countries, provides guidance on how businesses and organisations can operate in a socially responsible way. Holistic in its approach, ISO 26,000 addresses seven core subjects of social responsibility that are relevant to every organisation (ISO, 2014, pp. 5-7):

- organisational governance;

- human rights;

- labour practices;

- the environment;

- fair operating practices; 
- consumer issues;

- community involvement and development.

Each of these core subjects, outlined in Clause 6 of the standard, includes a number of issues of social responsibility - 37 in total with related actions and expectations (ISO, 2014, pp. 5, 15-16).

The Global Reporting Initiative (GRI) is another international independent standards organisation that sets the norms for ethical business behaviour. The mission of this not-for-profit, network-based organisation is to make sustainability reporting a standard practice. GRI promotes the use of sustainability reporting as a way for organisations to become more sustainable and contribute to sustainable development. To enable all companies and organisations to report their economic, environmental, social and governance performance, GRI produces free Sustainability Reporting Guidelines (ISO and GRI, 2014, p. 2).

In May 2013, GRI released its fourth generation of Sustainability Reporting Guidelines - G4. The GRI Guidelines organise Specific Standard Disclosures into three categories - Economic, Environmental and Social. The Social category is further divided into four sub-categories, which are Labour Practices and Decent Work, Human Rights, Society and Product Responsibility. The GRI aspects are set out within each sub-category and among them, for example, it is possible to find such as (ISO and GRI, 2014, pp. 18-19):

- G4-LA1: Total number and rate of new employee hires and employee turnover by age group, gender, and region;

- G4-LA2: Benefits provided to full-time employees that are not provided to temporary or part-time employees, by significant locations of operation;

- G4-LA3: Return to work and retention rates after parental leave, by gender, etc.

There are no specific economic and social indicators connected with the protection of employees' and pensioners' claims in case of company insolvency among GRI Sustainability Reporting Guidelines G4, which makes it difficult to identify and tackle social consequences of insolvency.

Thus, we may draw some general conclusions based on the investigation of existing conceptual approaches to CSR. The concept of CSR has been introduced all around the world. In recent years multi-stakeholder (ISO, GRI, etc.) and inter-governmental 
(UN, EU, etc.) initiatives have established a structural basis for the promotion of CSR standards and their application, reporting, monitoring, auditing and certification. It is noticeable that CSR norms in existing initiatives tie labour and human rights together but there are no norms or KPIs connected with the protection of employees' and pensioners' claims in case of company insolvency among them.

\subsection{Case analysis of CSR and sustainability strategy: the interaction of social responsibility and companies' insolvency in a real corporate practice}

In the context of the objective and comprehensive analysis of the implementation of CSR and sustainability strategy ideas and for answering the second question 'How do companies implement concepts and requirements of disclosing social and employee-related matters in real practice?', we have investigated the practice of the leading telecommunications companies. They are the first companies that come to mind as a beacon of good corporate governance: 54 telecom companies on the 2018 Forbes Global 2000 list claim more than USD 3.4 trillion in assets and totalled nearly USD 1.5 trillion in revenue last year (Forbes, 2018). Three leading positions are taken by non-EU members companies, that do not fall within the scope of the Directive 2014/95/EU of the European Parliament: AT\&T, Inc. (United States, www.att.com), Verizon Communications, Inc. (United States, www.verizonwireless.com) and China Mobile, Ltd. (China, Hong Kong, www.chinamobileltd.com).

AT\&T, focused on its vision 'Connect to Good', has established a 10-year roadmap of goals and targets to serve as milestones on the road of sustainable development. Top-line goals are broken into two timeframes - 2020 and 2025 - to provide a midway check-in, with supporting targets to show the progress along the way. AT\&T reports show the company's efforts to achieve Network and Customers Goals, Supply Chain Goals, and Communities Goals (AT\&T Inc., 2015, p. 3). To assess how AT\&T is doing, several key performance indicators (KPI) to measure the company's progress year-over-year have been established and reported. KPIs cover three areas: People, Planet, and Possibilities as those most important to the company's stakeholders and business. AT\&T also declares the support of SDGs such as: SDG 3.6, SDG 4, SDG 5, SDG 8, SDG 9, etc. and discloses 
the information in accordance with GRI Guidelines. 2017 Corporate Responsibility Update presents the scope of the relevant information. No figures and facts or non-financial information on CSR and sustainability strategy were included into AT\&T Inc. annual report (AT\&T Inc., 2017).

In 2017, Verizon presented Corporate Responsibility Report CRC priorities (humanability, product responsibility, environment, etc.) and SDGs (SDG 4 and SDG 8) as a part of their strategy and included corporate responsibility highlights in its annual report. Verizon also discloses the information in accordance with GRI Guidelines (Verizon, 2017, p. 7).

China Mobile has declared its sustainability policy based on principals of Wider Connections, Better Value, and Stronger Capabilities. China Mobile implemented the strategic corporate social responsibility management which has been embedded in corporate strategy and operations since 2006 and has gradually established the strategic CSR management system including four modules of strategy, implementation, performance and communication. In 2017, the company followed the United Nations Global Compact Ten Principles, the UN 2030 Agenda for Sustainable Development and Chinese CSR Report Preparation Guide (CASS-CSR 4.0) issued by the Chinese Academy of Social Sciences, the GRI Sustainability Reporting Standards of the Global Sustainability Standards Board (GSSB), the ISO 26,000 and the HKEx Environmental, Social and Governance Reporting Guide, and referred to the evaluation criteria of the Dow Jones Sustainability Indices (DJSI) during the 2017 sustainability reporting process. The 2017 Sustainability Report of China Mobile Limited was assured by Ernst \& Young (China Mobile Limited, 2018a, p. 58). No figures and facts or non-financial information on CSR and sustainability strategy were included into China Mobile Ltd. annual report (China Mobile Limited, 2018b).

All three leading telecommunications companies, as noticed before, are not European companies. Therefore, it is reasonable to analyse the practice of implementation of CSR and sustainability strategy ideas in the EU Member States. A case in point is A1 Telekom Austria Group, listed on the Vienna Stock Exchange and currently operating in seven European countries including Belarus. In pursuing its corporate strategy, the A1 Telekom Austria Group commits itself to the targets of the triple bottom line of sustainable 
development ('People, Planet, Profit'). The Telekom Austria Group's sustainability strategy is based on the issues of 'Customer Focus', 'Data Privacy' and 'Network Quality and System Stability'. Targets, measures, and outcomes of company's sustainability strategy, based on four strategic action areas 'Network \& Customers', 'Environment', 'Employees', and 'Society' were disclosed in the company sustainability report under the banner of 'Dvolution'.

Consolidated non-financial report of A1 Telekom Austria Group was prepared in accordance with Section 267a (6) of the Austrian Company Code (UGB) on environmental, social and employee matters, as well as combating corruption and bribery and included in Annual Financial Report 2017, prepared according to $\S 124$ Para 1 Stock Exchange Act. In accordance with the GRI Standards under the core option as well as the Telecommunications Supplement Pilot Version 1.0, the GRI Content Index was prepared as a separate report. This report lists all topics that have been identified as material for A1 Telekom Austria Group as a whole in the course of the materiality assessment in 2017. The company is also expressly committed to the UN Global Compact and makes contributions to the Sustainable Development Goals (SDG) of the United Nations. Finally, such sections as Employees, Social and Ecological Responsibility, Compliance, Consolidated Non-Financial Report, GRI Content Index, Sustainability KPIs are included in Combined Annual Report 2017 of A1 Telekom Austria Group. As it is noticed from the description of the A1 Telekom Austria Group practice, European companies have more rich reporting habits. This practice and integrated viewpoint have also led to the first-time publication by A1 Telekom Austria Group of a combined annual and sustainability report for the year 2017 (A1 Telekom Austria Group, 2017).

Nevertheless, based on the managerial and consolidated financial statements information, the assumption about the absence of the interaction of social responsibility and companies' insolvency in a real corporate practice can be made. There is no evidence of disclosing protection claims matters in case of company insolvency in the corporate practice of neither American or Chinese nor European companies. 


\section{Social responsibility aspects of companies' insolvency}

As it is seen from the list of KPIs by Directive 2014/95/EU of the European Parliament and ISO 26,000 clauses based on GRI aspects by Sustainability Reporting G4 Guidelines, there are no indicators related to protection of job losses or significant pension and wage benefits in case of corporate insolvencies. No relevant indicators, figures or managerial information were found in the statements of the leading telecommunications companies, mentioned above.

In response to the next question of our investigation ('What is the interaction of social responsibility and companies' insolvency?'), attention should be drawn to the fact, that employees have long been considered worthy of special protection if a company becomes insolvent. This has been seen to be appropriate because employees are less able to manage the risk of the loss they suffer if their employer becomes insolvent. Whilst shareholders can diversify their investment portfolio to eliminate or hedge against risk, and creditors may diversify their customer base or seek guarantees or security, employees typically have only one employer and they are accordingly exposed to that employer for the entirety of unpaid wages, superannuation, leave or redundancy entitlements with very little capacity to reduce that risk.

As Sarra (2006, p. 1) underlines employees are some of the most vulnerable creditors when firms experience financial distress. Unlike sophisticated creditors who can take steps to register security to protect their credit position and have easier access to information to manage their credit exposure, employees often suffer a loss of wages and benefits owed in addition to losing their jobs on a firm's insolvency. Further, it is suggested by Whelan and Zwier (2005, p. 4) that the personal and social costs of business failure fall disproportionately on employees.

All these problems clearly underline the importance of disclosing social responsibility aspects of companies' insolvency in their financial statements as one of non-financial social and employee matters. However, so far, this critical aspect has been neglected. Partially, this situation can be explained by the fact that the number of countries has a system of priorities or preferences for wage and related claims. Ranking of priority claims refers to where, in the hierarchy 
of credit claims, wages and other compensation claims are placed. So, a priority or preference system is one in which employees (former employees) with wage and other compensation claims are given a statutory priority over other classes of creditors.

The following Table 1 reproduces the matrix of the types of priorities or preferences for wage and related claims existing in 62 countries presented by Sarra (2008).

Table 1. The matrix of the types of priorities or preferences for wage and related claims

\begin{tabular}{ll}
\hline Model & Examples \\
\hline $\begin{array}{l}\text { Absolute priority, including over secured } \\
\text { creditors, for a capped amount }\end{array}$ & $\begin{array}{l}\text { Brazil, Chile, Colombia, } \\
\text { Malaysia }\end{array}$ \\
\hline $\begin{array}{l}\text { Restricted absolute priority, secured creditors } \\
\text { and employees paid preferentially only for } \\
\text { a percentage of assets }\end{array}$ & Czech Republic \\
\hline $\begin{array}{l}\text { Split priority, distinguishing types of employ- } \\
\text { ees in ranking }\end{array}$ & India \\
\hline Priority as a cost of bankruptcy & Slovenia \\
\hline $\begin{array}{l}\text { Priority after secured creditors but prior to } \\
\text { floating security creditors }\end{array}$ & $\begin{array}{l}\text { Australia, Israel, Ghana, } \\
\text { Slovakia }\end{array}$ \\
\hline $\begin{array}{l}\text { Priority by time frame, with different priorities } \\
\text { for different time frames }\end{array}$ & France \\
\hline Priority over unsecured creditors & Austria, Hungary, Japan, \\
& Norway, Thailand, and \\
\hline No preferential treatment & Switzerland \\
\hline
\end{tabular}

Source: based on Sarra (2008).

Sarra's investigation showed that on May 1, 2008, 25 jurisdictions (i.e. $40 \%$ of the countries in the study), granted absolute or so-called super-priority for wage and related claims. A super-priority allows employees to receive some portion of their claims on a basis that ranks ahead of all creditors: both secured and unsecured.

In some jurisdictions wage claims rank as unsecured claims that means ranking pari passu with other unsecured creditors and behind secured creditors that have a lien on an item of the company's property. In the United States, for example, mortgage lenders 
and car lenders are secured creditors. They have voluntary liens on the insolvent company property. Super-priority of employees in such countries as: Brazil, Chile, Colombia, Malaysia, etc. ignores the privileged position of secured creditors. Thus, a super-priority is a specific mechanism to ensure that employees' claims are first in line to be satisfied with any financial problems of the company. The policy rationale for this protection is likely to be clearly evident because of the exceptional vulnerability of employees at the point of enterprise insolvency.

Together with a super-priority system there is a restricted absolute priority system (secured creditors are paid preferentially out of definite percentage of assets of the insolvent firm, whereas the rest of the estate must be available to meet employee claims on a full priority basis); a split priority system (only particular types of employees are given a special or super-priority); a priority for employee compensation claims after secured creditors but prior to floating security creditors; a priority based on particular timeframe (super-priority for wages not paid in definite number of days prior to the insolvency proceedings).

So, further 13 countries in Sarra's investigation (Sarra, 2008, pp. 13-14), i.e. $21 \%$ of the 62 jurisdictions studied, create equity of priority with secured claims or grant a partial priority over secured claims. 17 jurisdictions, i.e. $27 \%$ of the total, grant a priority over unsecured claims only. $11 \%$ of the total, i.e. 7 countries, offer no priority for wage claims. Thus, about $61 \%$ of the jurisdictions accord some priority over secured claims or a priority equal to secured claims for employee wage and related compensation claims and almost $39 \%$ of the jurisdictions grant a priority over unsecured claims or no priority at all.

On the other hand, some jurisdictions (almost one half of the 62 studied by Sarra (2008, p. 30)) combine different kinds of priorities and preferences with either wage or pension insurance systems or guarantee funds that project employee occupational benefits and wage-related benefits in case of employer insolvency. The greatest advantage of such schemes is that they place the risk of non-payment with the guarantee fund, government agency or insolvency insurance schemes providing the funding out of general tax revenue, contributions paid by employers, premiums paid by corporations and other business enterprises, donations, contributions and amounts 
recovered by administrators, etc. and usually enable employees to have some immediate realization of their claims.

Most recent surveys by P. Secunda (Secunda, 2015, p. 924), based on the approach of G. Johnson (Johnson, 2006, pp. 4-6), classify all existing models of treatment of wage and pension claims during insolvency in 34 OECD countries as shown in Table 2.

Table 2. Classification of OECD countries by models of treatment of wage and pension claims during insolvency

\begin{tabular}{ll}
\hline Model & OECD Countries \\
\hline $\begin{array}{l}\text { 1 Bankruptcy priority, little or no } \\
\text { guarantee }\end{array}$ & $\begin{array}{l}\text { Chile, Mexico, New Zealand, Turkey } \\
(4)\end{array}$ \\
\hline 2.1 Hybrid, bankruptcy priority \\
$\begin{array}{l}\text { and guarantee for both pension and } \\
\text { wages (robust) }\end{array}$ & $\begin{array}{l}\text { Belgium, Canada, Denmark, Iceland, } \\
\text { Ireland, Israel, Italy, Norway, Sweden, } \\
\text { Switzerland, United Kingdom (11) }\end{array}$ \\
\hline $\begin{array}{l}\text { 2.2 Hybrid, bankruptcy priority and } \\
\text { guarantee for either pension or wages } \\
\text { (limited) }\end{array}$ & $\begin{array}{l}\text { Australia, Czech Republic, France, } \\
\text { Greece, Hungary, Japan, Republic of } \\
\text { Korea, Luxembourg, Netherlands, } \\
\end{array}$ \\
$\begin{array}{l}\text { Poland, Portugal, Slovakia, Slovenia, } \\
\text { Spain, United States (15) }\end{array}$ \\
\hline $\begin{array}{l}\text { 3 No or limited bankruptcy priority, } \\
\text { but some form of guarantee }\end{array}$ & Austria, Estonia, Finland, Germany (4) \\
\hline
\end{tabular}

Source: own study based on Secunda (2015).

Thus, nowadays many of the OECD countries have guarantee schemes that will help pay for some employee wage-based benefits upon insolvency, at least for a designated period before the insolvency and up to a predetermined capped amount. Canada, for example has such a wage-guarantee scheme under its Wage Earner Protection Program (WEPP) (Employment and Social Development Canada, 2019).

In addition, as for wage and related claims benefits, many countries have different pension guarantee schemes. The Pension Benefit Guaranty Corporation (PBGC), that is limited to pension plans, and then only to private sector defined benefit pension plans in the United States, is a prime example of a pension guarantee scheme. Similar organisations exist in the United Kingdom. The Commonwealth government has implemented taxpayer-funded safety-net schemes for employee entitlements. The current scheme of general application is the Pension Protection Fund (PPF). PPF was established 
for purposes of providing payment to employees in occupational defined benefit plans for both unpaid contributions and unfunded liabilities where the sponsoring employer became insolvent (Pension Protection Fund, 2018).

The public policy goal behind such schemes is to provide a more timely method of payment of wages and benefits to employees when their employers become insolvent. They also may play an important role in the insolvency process itself by taking on the pension or wage-related credit claims of employees. This is beneficial because such a guarantee institution becomes a large creditor with correspondingly greater ability to have its concerns met during the insolvency process (Secunda, 2015, p. 885).

Nowadays the largest number of countries has chosen a hybrid model of both ranking of priority and using different guarantee institutions or guarantee schemes because such a choice gives greater protection for employees. Nevertheless, despite the pros and cons of the particular schemes of protection of workers' wage and pension claims (Goldowitz, 2016; Anderson, 2014, etc.), problem is that this issue usually comes up to the legislature, or to the public's attention, when a big bankruptcy occurs, like that of LTV Steel, Enron, or the city of Detroit (Kimhi, 2015, p. 148).

\section{Reasons for changing KPIs of non-financial social and employee matters}

Although there are significant differences between the insolvency systems in different countries and the treatment of wage and pension claims during company insolvency, some important conclusions and summaries do exist (responding to the fourth question of our study: 'Should social responsibility aspects of companies' insolvency be presented among CSR KPIs?'). As an initial matter, some countries have little or no priorities and preferences guarantee for employees during insolvency (see Table 1). Other countries do not have wage or pension guarantee funds (see Table 2). Belarus is among the last countries not included in the OECD group.

In Belarus, similarly to the majority of international jurisdictions, priority creditor status is the primary form of protection conferred upon employees in the case of corporate insolvency. According to 
Article 141 of the Law 'On Economic Insolvency (Bankruptcy)' of July 13, 2012 (Bankruptcy Law), the claims of employees have the second rank after unpaid health and disability compensations and expenses of the bankruptcy proceedings (Karaleu, 2016, pp. 46-47).

In contrast to many other jurisdictions, priority amounts payable to employees under the Belarusian insolvency regime are not capped. Employees are entitled to priority payment in corporate insolvency of all unpaid wages, superannuation contributions, leave entitlements and retrenchment payments. However, pursuant to Article 147 of the Bankruptcy Law, the claims of employees are considered satisfied if there are no sufficient funds of the insolvency estate. Thus, there is every chance that the employee will not receive any payments for their claims in the process of corporate insolvency.

Numerous jurisdictions, as it was mentioned above, have chosen to create guarantee funds or insolvency insurance schemes that are aimed at redressing the problems faced by employees in realising their wage and pension claims. There are no such funds in Belarus and some other countries. However, even such funds are not absolutely effective: they are normally fully able to fulfil their duties, but in the case of big, state-owned or state-controlled, entities being declared insolvent, they usually do not have the funds to pay all the employees' claims. Such a situation occurred in the early 2000s, when a major Polish shipyard declared bankruptcy and Poland's Wage Guarantee Fund was unable to pay the claims of several thousand employees. Auxiliary budget grants were then given to the Fund to alleviate the problem. According to Sarra's opinion (Sarra, 2008, p. 242), should a major employer declare bankruptcy in the future, the situation would most probably be repeated.

The same dramatic situation we have in our Belarussian practice with pensioners' claims in case of company insolvency. According to the Law of the Republic of Belarus 'On Basics of State Social Insurance' of January 31, 1995 (Social Insurance Law), the types of state social insurance payments included, among other payments, pensions for age, disability, loss of a breadwinner, and length of service. However, pursuant to Article 2 of the Social Insurance Law, it was fixed that a person becomes entitled to the pension benefits from the state social insurance system only if contributions from their salary have been made. The length of service and the individual salary coefficient for the appointment of a pension and its amount 
calculation is determined only in case of making established by the low payments to the off-budget State Social Security Fund of the Ministry of Labour and Social Protection of the Republic of Belarus (Fund). Most of the insolvent companies lack the resources to make such contributions to the Fund and their employees automatically forfeit their right to a pension for non-payment period.

So, as it is clear from the description of the national practice of Belarus, the issue of wage and pension claims requires public policy debate and choices. While the debates have been rigorous in some jurisdictions, there is relatively little understanding that it is extremely important to implement social responsibility aspects of companies' insolvency globally. Some jurisdictions have not created an effective national system of wage and pension claims protection and companies should provide this protection as one of the basic elements of CSR.

\section{Conclusions}

Much existing literature in management stresses the potential positive relationship between ethical business and financial returns. This idea has become conventional wisdom within public debates around CSR and is strongly institutionalised in the field of socially responsible business and increase the transparency of financial reports.

Ideas and principles of sustainable development and the practice of CSR as a paradigm for firms and businesses to follow do not cover the whole spectrum of social aspects required to ensure the holistic approach to tackling this issue, such as the interaction with companies' insolvency. On the other hand, the study of social and employee-related matters companies are expected to disclose in non-financial reports shows no social responsibility aspects of companies' insolvency. From this point of view, it is vital to extend KPIs by indicators related to pension and wage benefits in case of insolvencies.

In the interim, companies' insolvencies around the world have not only resulted in job losses for employees, but also in losses of significant pension and wage benefits. Employees are considered the most vulnerable of company creditors in the insolvency process because of their lack of ability to diversify their risk, lack of voice 
or information, resources or bargaining power to realise their claims individually.

The treatment of employee wage and other compensation claims after employer insolvency using super-priority regime is not enough. Even in spite the fact that the EU Directive sets a minimum standard for protection of employee claims in insolvency in all EU countries (through a transposition by a national law or a decree) and requires the Member States to set up an institution to guarantee some or all of these employee claims, the efficiency and outcome of insolvency is different. Therefore, it is not only necessary to improve the economic mechanism for higher protection of employee claims but also to stimulate every company to have the system of measures for employee wage and pension claims protection in case of insolvency. Experience of Belarus and some other countries demonstrate convincingly that these measures are reasonable and vital: there is every chance that the employee will not receive any payments for their claims.

\section{References}

A1 Telekom Austria Group (2017), “Combined Annual Report 2017”. Retrieved from https://cdn1.a1.group/final/en/media/pdf/Combined\%20Annual\%20 Report_2017.pdf (accessed 13 February 2019).

Anderson, H. (2014), "Pressing the Right Buttons: Australian Case Studies in the Protection of Employee Entitlements Against Corporate Insolvency”, International Labour Review, Vol. 153, Issue 1, pp. 117-142.

AT\&T Inc. (2015), “Connect to Good: A Roadmap to 2025”. Retrieved from https:// about.att.com/ecms/dam/csr/2025-goals/2025-ATT-Goals-PDF-Overview.pdf (accessed 13 February 2019).

AT\&T Inc. (2017), “2017 Annual Report”. Retrieved from https://investors.att. com/ /media/Files/A/ATT-IR/financial-reports/annual-reports/2017/complete-2017-annual-report.pdf (accessed 13 February 2019).

Barbier, E., Burgess, J. (2017), “The Sustainable Development Goals and the Systems Approach to Sustainability”, Economics: The Open-Access, Open-Assessment E-Journal, Vol. 11, Issue 2017-28, pp. 1-23.

China Mobile Limited (2018a), “2017 Sustainability Report”. Retrieved from https://www.chinamobileltd.com/en/ir/reports/ar2017/sd2017.pdf (accessed 13 February 2019).

China Mobile Limited (2018b), "Riding on the Trend. Annual Report 2017". Retrieved from https://www.chinamobileltd.com/en/ir/reports/ar2017.pdf (accessed 13 February 2019).

Employment and Social Development Canada (2019), “Wage Earner Protection Program for an employee: Overview”. Retrieved from https://www.canada.ca/ 
en/employment-social-development/services/wage-earner-protection/employee.html (accessed 13 February 2019).

EU (nd), Corporate Social Responsibility (CSR). Retrieved from http://ec.europa. eu/growth/industry/corporate-social-responsibility/ (accessed 1 July 2018).

European Commission MEMO/14/301 (2014), "Disclosure of Non-financial and Diversity Information by Large Companies and Groups - Frequently Asked Questions”. Retrieved from http://europa.eu/rapid/press-release_MEMO14-301_en.htm (accessed 1 July 2018).

European Union (2014), "Directive 2014/95/EU of the European Parliament and of the Council of 22 October 2014 Amending Directive 2013/34/EU as Regards Disclosure of Non-financial and Diversity Information by Certain Large Undertakings and Groups”, Official Journal of the European Union, L 330, pp. 1-9.

Forbes (2018), “Global 2000: The World’s Largest Public Companies”. Retrieved from https://www.forbes.com/global2000/\#157bb644335d (accessed 1 July 2018).

Goldowitz, I. (2016), “Response to Professor Paul Secunda’s Comparative Analysis of the Treatment of Employment Claims in Insolvency Proceedings and Guarantee Schemes in OECD Countries”, Fordham Urban Law Journal, Vol. 41, Issue 3, pp. 1027-1040.

ILO (2017), "International Labour Organization Tripartite Declaration of Principles Concerning Multinational Enterprises on Social Policy”. Retrieved from http://www.ilo.org/empent/Publications/WCMS_094386/lang--en/index.htm (accessed 1 July 2018).

ISO (2014), “ISO 26000 and SDGs”. Retrieved from https://www.iso.org/files/live/ sites/isoorg/files/store/en/PUB100401.pdf (accessed 13 February 2019).

ISO and GRI (2014), "GRI G4 Guidelines and ISO 26000:2010: How to Use the GRI G4 Guidelines and ISO 26000 in Conjunction”. Retrieved from https://www. iso.org/files/live/sites/isoorg/files/archive/pdf/en/iso-gri-26000_2014-01-28. pdf (accessed 1 July 2018).

Johnson, G. (2006), “OECD, Insolvency and Social Protection: Employee Entitlements in the Event of Employer Insolvency". Retrieved from http://www. oecd.org/corporate/ca/corporategovernanceprinciples/38184691.pdf (accessed 1 July 2018).

Karaleu, Y. (2016), "Insurance for Handling Employee Entitlements in the Event of Employer Insolvency (Bankruptcy)”, Nauki o Finansach (Financial Sciences), No. 2(27), pp. 38-48.

Kimhi, O. (2015), "Getting More Than Justice on Paper: Bankruptcy Priorities and the Crisis of Unpaid Wages”, Fordham Urban Law Journal, Vol. 44, Issue 1, pp. 107-149.

McWilliams, A., Siegel, D. (2001), “Corporate Social Responsibility: A Theory of the Firm Perspective”, Academy of Management Review, Vol. 26, No. 1, pp. 117-127.

OECD (2011), “OECD Guidelines for Multinational Enterprises”, OECD Publishing. Retrieved from http://dx.doi.org/10.1787/9789264115415-en (accessed 1 July 2018).

Pension Protection Fund (2018), “General Guidance on Insolvency and the Assessment Period”. Retrieved from file://C:/Users/\%D0\%9C\%D0\%B0\%D1\%80 
\%D0\%B8\%D1\%8F/Downloads/general_guidance_on_insolvency_and_the_ assessment_period.pdf (accessed 13 February 2019).

Sarra, J. (2006), “A Brief Overview of the Treatment of Employee Claims and Collective Agreements in Canadian Insolvency Law”. Retrieved from https:// www.iiiglobal.org/sites/default/files/JanisSarra.pdf (accessed 1 July 2018).

Sarra, J. (2008), “Recognizing Workers' Economic Contributions: The Treatment of Employee and Pension Claims During Company Insolvency, a Comparative Study of 62 Jurisdictions”. Retrieved from http://docplayer. net/52851478-A-comparative-study-of-62-jurisdictions.html\#download_tab_ content (accessed 1 July 2018).

Secunda, P. (2015), “An Analysis of the Treatment of Employees Pension and Wage Claims in Insolvency and Under Guarantee Schemes in OECD Countries: Comparative Law Lessons for Detroit and the United States”, Fordham Urban Law Journal, Vol. 41, Issue 3, pp. 869-937.

Verizon (2017), “2017 Corporate Responsibility Report”. Retrieved from https:// www.verizon.com/about/sites/default/files/2017_Verizon_Corporate_Responsibility_Report.pdf (accessed 13 February 2019).

Whelan, J., Zwier, L. (2005), "Employee Entitlements and Corporate Insolvency and Reconstruction”. Retrieved from https://law.unimelb.edu.au/_data/assets/ pdf_file/0015/1710015/95-Protectionofemployeeentitlements_final_12.pdf (accessed 1 July 2018). 